\title{
Status of Mangroves in Flat Bay coast after eight years ahead the catastrophic events in Andaman Islands.
}

\author{
Yuvaraj. $E^{* 1}$, Dharanirajan. $\mathrm{K}^{2}$ \\ ${ }^{1}$ Research Scholar, Department of Disaster Management, Pondicherry University, Port Blair. \\ ${ }^{2}$ Assistant Professor, Department of Disaster Management, Pondicherry University, Port Blair.
}

\begin{abstract}
Sea level rise is the inevitable outcome of global warming, climate change and other catastrophic events like tsunami, land tilt, cyclones etc which lead to sudden change in sea level. As the sea level is rise mangroves are the first responders that affect in the coastline. Mangrove plays an important role in preventing coastal erosion, as it is an authentic matter this study was performed for analysing some of the mangrove species are sensitive to catastrophic sea level rise and its resulting inundation. Coastal areas of Flat bay were taken for this study where it is estimated that $46 \%$ of coastline was covered by mangroves. December 2004 tsunami and tectonic tilt of South Andaman results in inundation of the flat bay coastal regions and the raised sea level doesn't retrieve it leads to drastic changes in the mangrove environment of sippighat creek and nearby areas. Satellite image shows submerged and affected mangroves in the inundation caused by tsunami. In this area on comparing 1998 and 2011 satellite images out of 388.81 ha of mangroves 176.92 and 57.67 ha are affected and submerged respectively due to inundation and sea level rise. Submergence and degradation takes place in the seaward mangroves and the landward or riverine mangroves consequently invade to the land results in changes of mangrove distribution. Rejuvenation of mangroves occurs rapidly in the inundated areas of sippighat coast where 9.18 ha of mangrove community habitat at juvenile and sapling stage were observed in the field. The present status of mangroves in flat bay coast was calculated as 163.40 ha. These field investigations were compared with geospatial analysis and concluded the impacts of sea level rise on mangroves. Finally from the field survey and geospatial analysis evaluated that seaward mangroves are degraded more and landward mangroves are migrating landward.
\end{abstract}

Keywords - Mangrove, Remote Sensing, tsunami inundation, South Andaman, Flat Bay,

\subsection{Mangrove Ecosystem}

\section{Introduction}

Mangroves are salt tolerant shrubs and trees that form highly productive intertidal ecosystems in tropical and subtropical regions [1-2] (Benjamin, 2011; Alongi, 2002). Its habitat exist in tidal exposure depends on the balance between sea level and sediment accumulation [3] (Chapman 1960). Mangrove forest protects shoreline and inland areas from natural hazards like Tsunami, cyclone, storm surge and acts as barriers along the coast [4] (Barbier, 2006). Andaman mangrove ecosystem is one of the richest biodiversity among the Indian subcontinent, which has a wide biodiversity of the associated species and protects the coastline from the erosion [5] (ISRO, 2003). These are most threatened and vulnerable ecosystems worldwide significant amount of the loss is triggered by natural forces, such as tsunamis, cyclones [6] (Chan and Baba, 2009) and the threat of global warming [7] (Gilman et al, 2008).

\subsection{Tsunami inundation impacts on South Andaman mangroves}

In South Andaman the inundation caused by December 2004 Tsunami was perpetuated by sea level rise [8] (Dharanirajan et al., 2006). Subsidence of the landmass in the earthquake results in rise of sea water level by about one meter [9] (Sudhir et al., 2005). Sea-level rise is a major threat for valued coastal ecosystems, including mangroves and other tidal wetlands and it is projected that future reductions occur in these coastal areas [10-11] (IPCC 1996, Gilman, 2004). Mangroves are one of the world's most threatened ecosystems for the of sea-level rise [7] (Gilman et al., 2008) which jeopardises the survival of individual mangrove trees as well as mangrove forest. As the sea level is rise consequently the inundation depth and salinity will increase results in degradation of seaward mangroves and migration of landward mangroves [12-14] (Naidoo, 1983; Lewis, 2005; Eric, 2007). Bathymetry and coastal profile are the most important parameter determining the sea level rise, coastal erosion and its impacts on Andaman mangroves [15] (Department of Ocean Development, 2005). Tsunami inundation causes the rise of water to 2 meter above the normal sea level in low lying areas of sippighat creek which invades upto $2000 \mathrm{~m}$ from the shoreline [16] (Subramanian et al, 2005) and affects the mangrove ecosystem. This inundation in mangroves of Sippighat area was results in submergence, degradation and growth retardation [17] (Dam Roy and Krishnan, 2005). It is in need to study these threatened ecosystem, 
Remote sensing has been widely proven to be essential in monitoring and mapping the mangrove ecosystems in regional as well as small scale [18-19].

\section{Material and Methodology}

\subsection{Study area}

South Andaman Island topography is a hilly terrain with small tracts of coastal fallow lands. Southern part of south Andaman consists of 3000 ha mangrove forest which comprises about $9.7 \%$ of total forest of South Andaman [20]; these mangrove species are mostly distributed on narrow patches on the sheltered coastal areas. [21]. Flat Bay coast were taken as study area for the present study, where the mangroves are existed on Garacharma, Sippighat, Dollygunj, Badmasphar, and Mitagari which covers above 23\% of total mangrove forest of South Andaman. In these areas different mangrove species distributed like Avicennia marina, A.officinalis, Rhizophora mucronata, R. Apiculata, Sonneratia alba, Acrostichum aureum, Acanthus illicofolius A. ebracteatus and Xylocarpus molluccenis are widely distributed. During 2006 Earthquake and Tsunami mangroves are severely affected particularly in sippighat are almost dissipated in some areas [8]. The objective of the study is to map the status of mangrove after the sea level rise on flat bay coast by the tsunami and land tilt in study area using Remote Sensing and GIS techniques.

\subsection{Materials}

Survey of India (SOI) toposheet (1979), Satellite imageries- IRS-ID LISS III (Feb. 2000), IRS-P6 LISS IV (March 2005, Feb 2009, May 2011) Measuring scale, GPS-Garmin etrex \& Garmin vista were used for this study. GIS (ArcGIS 9.1) and Remote Sensing (ERDAS IMAGINE 9.1) were used for Image processing and mapping purposes.

\subsection{Methodology}

Base map was prepared from the SOI toposheet. From the base map Satellite images were geo-rectified using ERDAS IMAGINE 9.1 software. The geo-referenced image was undergone spatial enhancement for the better clarity of the image features. Supervised classifications complemented by visual interpretations were used to map mangrove areas. Healthy, submerged and degraded mangroves were identified and delineated by the Interpretation key from Space Application Centre (SAC). The delineated mangroves are digitized in the ArcGIS software. Shoreline change analysis was done with respect to toposheet and satellite images. The erosion and accretion was calculated using Arctools for the entire flat bay coast and evaluated that there is not much impacts of shoreline change in mangroves. Mangroves in and around the inundated sites were delineated and consequent repercussions were analysed. In the field the degradation of mangroves was analysed in the appropriate location (fig 2). In the tsunami inundated sites mangrove species health was analysed visually and compared with undisturbed mangrove area.

\subsection{Tsunami Inundation}

\section{Result and discussion}

Tsunami inundation and Sea level rise was identified by comparing the IRS 1D and IRS P6 satellite images. The inundation of sea water on the mangrove environment and other land cover features was observed in the satellite images (Fig. 3). Submerged and degraded mangroves were also analysed. Inundation and sea level rise was confirmed by the field surveys. The total coastal length of flat bay covers $68.16 \mathrm{~km}$ among this most of the areas are affected by sea-level rise due to inundation caused by 2004 tsunami. Rise in sea level results in the shoreline changes and subsequent erosion which occur in the coast. Among the $68 \mathrm{~km}$ lengthy coast nearly $35 \mathrm{~km}$ were affected by tsunami inundation with the area of 578.5 ha (table 1 ). When compare to normal sea-level rise in fig. 4 which results in alteration of shoreline in minimum level but the catastrophic event leads to loss of enormous land area.

\subsection{Inundation impacts on mangroves}

Mangroves act as defenders for the tsunami waves which act as a barrier for the coast, which leads to submergence, destruction and degradation of its ecosystem. According to Toposheet the total mangrove in the study area was estimated to be 406.88 ha during 1979 and it rapidly degraded in the last two decades. These mortality conditions for mangroves occur particularly after the 2004 tsunami, it decreased up to 236 ha [8]. Low lying areas of sippighat mangroves is under the threat of erosion, it may due to the tsunami inundation impacts [16]. These catastrophic events cause severe impacts on mangroves than normal sea-level rise.

\subsection{Status of Mangroves}

The Remote sensing study clearly describe about the impacts of catastrophic sea level rise on mangrove environment. It was clearly digitized in the ARCGIS 10 software the output was shown in the fig. 5. It was 
evaluated that 57.67 ha of mangroves was submerged in the tsunami inundation. Nearly 176.92 ha of mangroves was damaged and affected by the tsunami waves. The sippighat mangrove swamps located in the low lying area which is affected severely by the tsunami, only 3 ha of mangroves was recovered with decreased and scattered biomass but rejuvenation of mangroves was observed in the inundation areas during field visit here the new mangrove saplings are rejuvenating in the inundated areas of landward side. Rejuvenation of mangroves was marked in GPS and mapped in ArcGIS and evaluated as 9.18 ha (fig. 6). It was finalise that 154.22 ha of mangroves was degraded (which includes submerged and severely affected) by the tsunami inundation and persistent sea level rise and the present status of mangroves was estimated that 163.40 ha in the study area (table.2).

\subsection{Mangrove Response}

Species like Acrostichum aureum, Acanthus illicofolius and Acanthus ebracteatus etc, are the seaward or proximal zone mangroves which are submerged and inundated by the tsunami. Further the landward mangrove species such as Rhizophora mucronata, $R$. apiculata and mangrove associated species like Acrostichum aureum, Fimbrisstylis littoralis, Nypa fruiticans, etc, are affected and retarded in growth due to increased inundation depth and high salinity. Avicennia marina and Sonneratia alba are the only two species stands remain due to its high salinity tolerant nature [17]. The satellite images show the degraded mangrove in the tsunami inundation in the seaward side. The field visit confirmed those seaward mangroves species are submerged and degraded while the mid stream and landward mangroves are affected by tsunami wave action; rejuvenation of mangroves also occurring in the landward side.

Figures and Tables

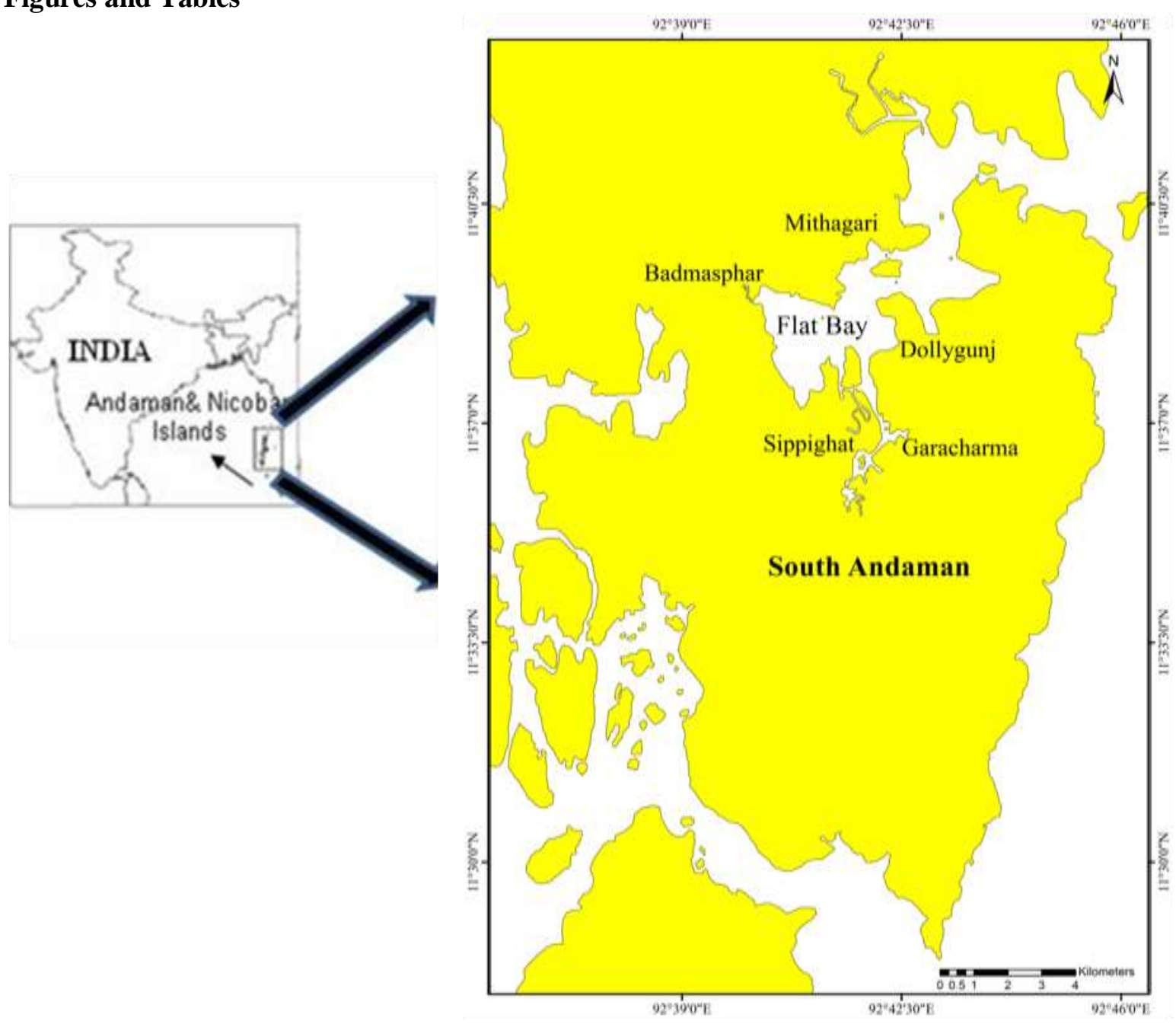

Fig 1: Study area map shows satellite image of study area. 

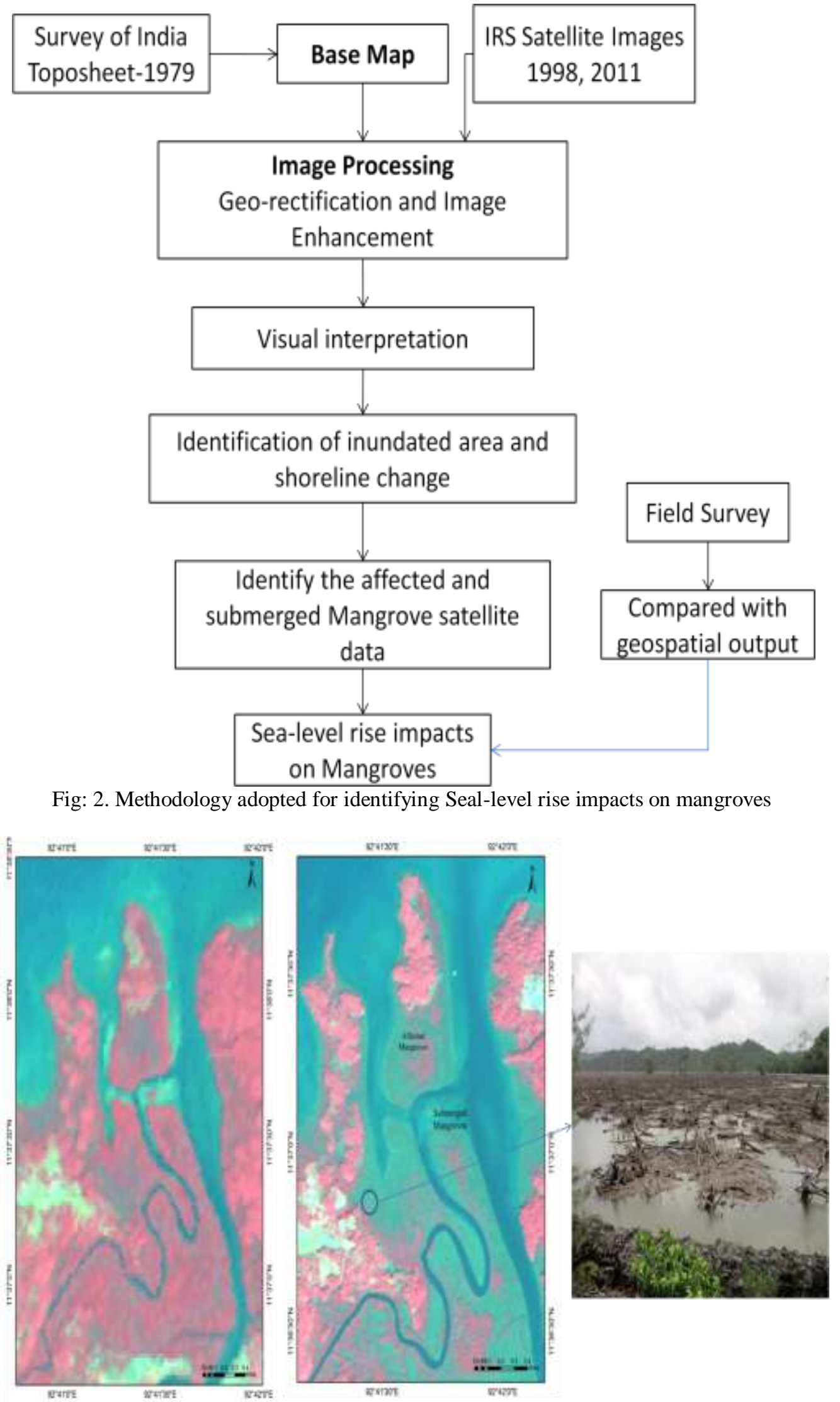

Fig 3: FCC images of IRS 1D (1988) and P6 (2011) shows the submerged and affected mangroves by tsunami and field photograph shows damaged mangrove condition. 


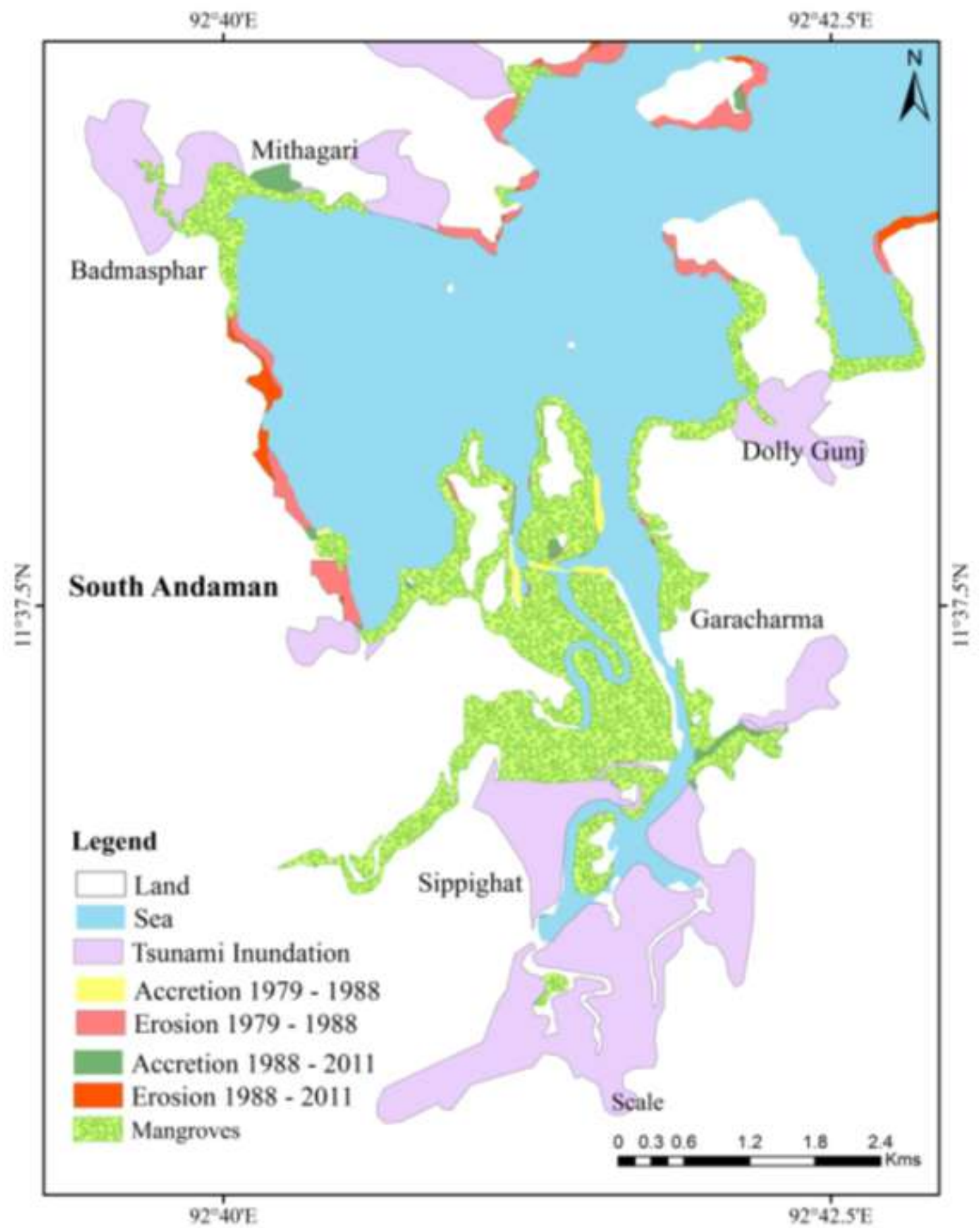

Fig 4: Map shows inundated area by December 2004 tsunami and Shoreline Change of study area in last three decades (1979 -2011). 

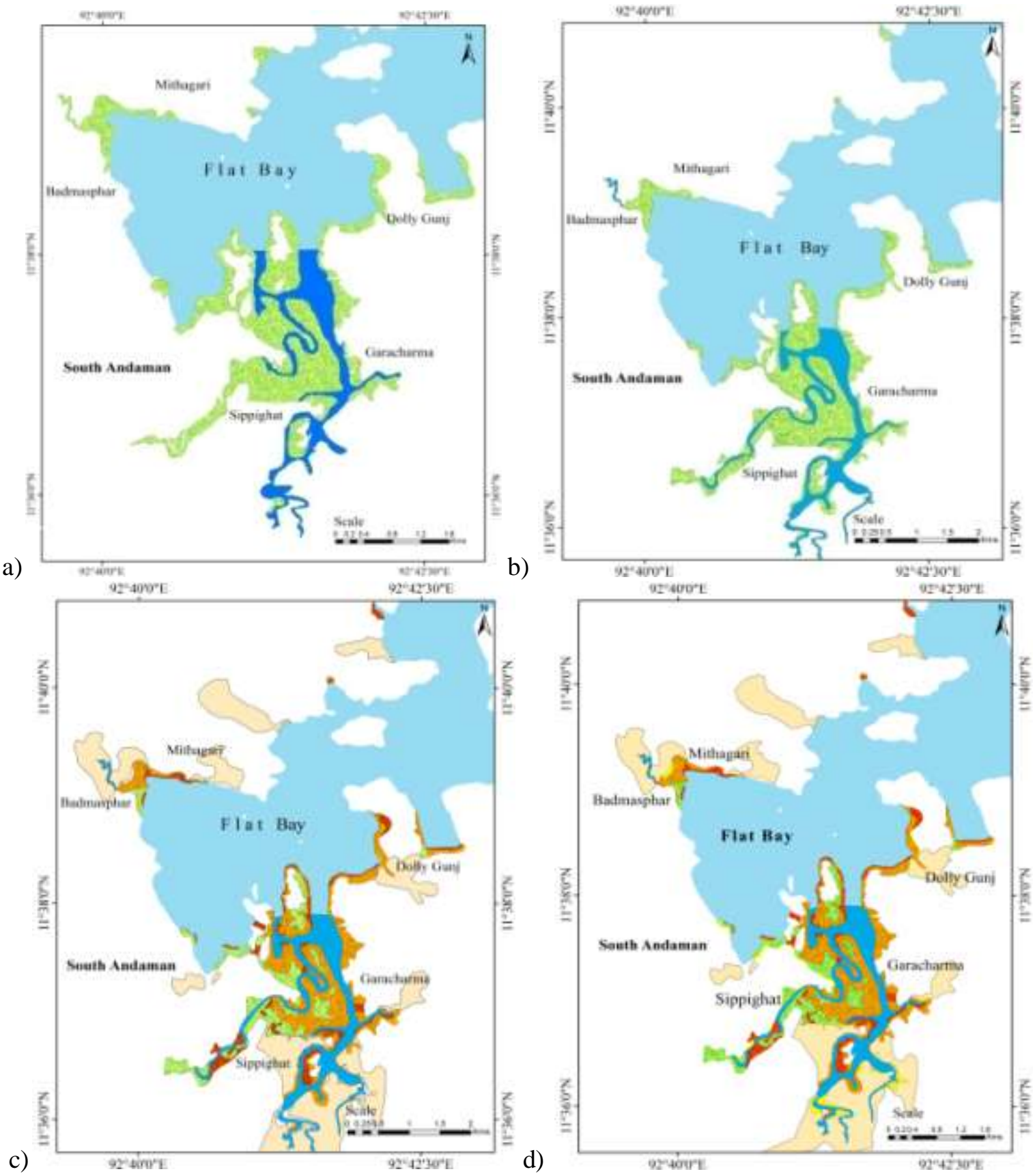

\section{Legend}

\section{Creek \\ Innundated Area \\ Mangroves \\ Submerged Mangrove \\ Affected Mangroves \\ Rejuvenated Mangrove 2012}

Fig 5: Mangrove dynamics for the Sea level rise. a) Status of mangroves in 1979, b) Status of mangroves in 1988 c) Status of Mangroves in 2011, d) Status of mangroves observed in the field and mapped. 

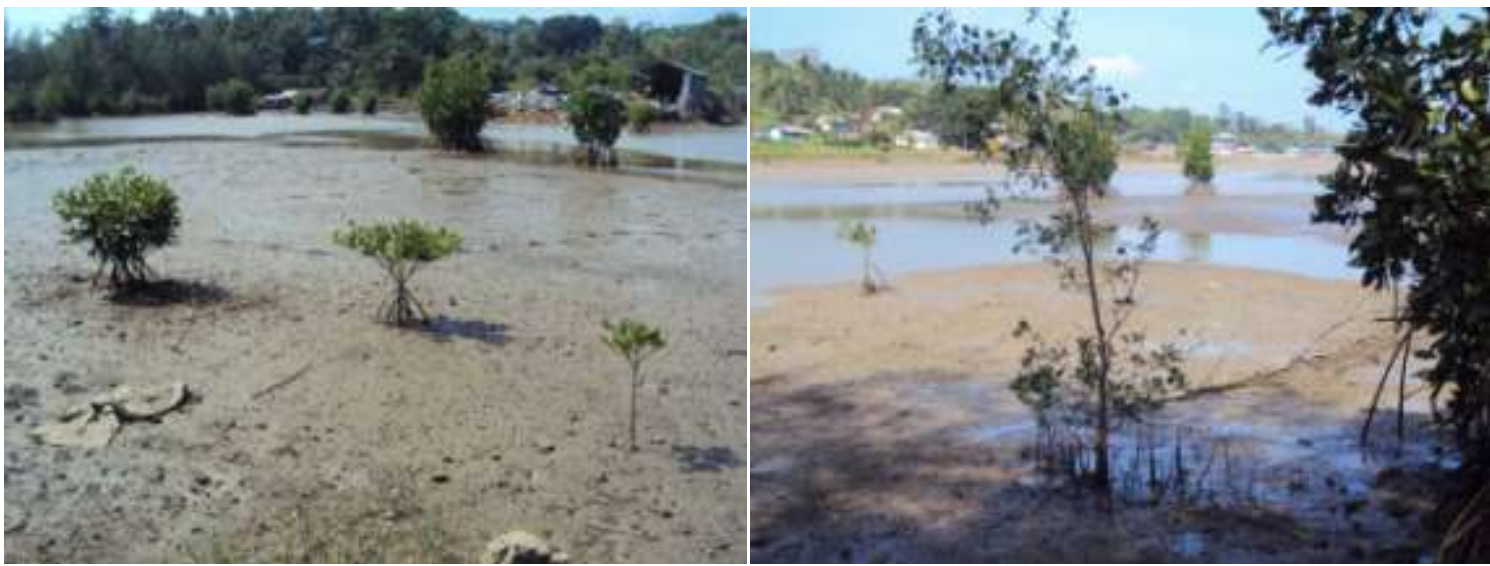

Fig.6: Field photographs of rejuvenating mangrove in inundation areas of Sippighat.

Table.1: Shoreline change and tsunami inundation of the study area

\begin{tabular}{|l|c|c|c|c|c|c|}
\hline Location & $\begin{array}{c}\text { Coastal } \\
\text { Erosion } \\
(1979- \\
2011)\end{array}$ & $\begin{array}{c}\text { Coastal } \\
\text { Accretion } \\
(1979- \\
2011)\end{array}$ & $\begin{array}{c}\text { Tsunami } \\
\text { Inundation } \\
\text { (ha) }\end{array}$ & $\begin{array}{c}\text { Average } \\
\text { distance } \\
\text { from } \\
\text { Shoreline } \\
\text { (m) }\end{array}$ & $\begin{array}{c}\text { Coast } \\
\text { length } \\
\text { covered by } \\
\text { mangroves } \\
\text { (km) }\end{array}$ & $\begin{array}{c}\text { Area of } \\
\text { Mangroves } \\
\text { Disturbed } \\
\text { (ha) }\end{array}$ \\
\hline Dolly Gunj & 25.15 & 2.23 & 46.83 & 997.65 & 8.52 & 26.08 \\
\hline Garacharma & 4.49 & 3.04 & 23.73 & 534.12 & 6.40 & 29.75 \\
\hline Sippighat & 5.38 & 2.92 & 290.16 & 1547.67 & 28.54 & 153.34 \\
\hline Badmasphar & 14.65 & 3.82 & 82.15 & 1023.87 & 4.63 & 9.28 \\
\hline Mittaghari & 17.43 & 5.41 & 135.63 & 1547.67 & 4.97 & 16.14 \\
\hline Total & $\mathbf{6 7 . 1}$ & $\mathbf{1 7 . 4 2}$ & $\mathbf{5 7 8 . 5 0}$ & $\mathbf{5 6 5 0 . 9 8}$ & $\mathbf{5 3 . 0 6}$ & $\mathbf{2 3 4 . 5 9}$ \\
\hline
\end{tabular}

Table 2: Mangrove dynamics after catastrophic sea-level rise December 2004 tsunami to 2012.

\begin{tabular}{|c|c|c|c|c|c|}
\hline Location & $\begin{array}{c}\text { Existed } \\
\text { Mangroves } \\
\text { (ha) }\end{array}$ & $\begin{array}{c}\text { Submerged } \\
\text { Mangroves } \\
\text { (ha) }\end{array}$ & $\begin{array}{c}\text { Affected } \\
\text { Mangroves } \\
\text { (ha) }\end{array}$ & $\begin{array}{c}\text { Rejuvenating } \\
\text { Mangroves } \\
\text { (ha) }\end{array}$ & $\begin{array}{c}\text { Present } \\
\text { Status (ha) }\end{array}$ \\
\hline Dolly Gunj & 33.84 & 7.43 & 18.65 & 1.20 & 8.96 \\
\hline Garacharma & 31.63 & 3.77 & 25.98 & 0.83 & 2.71 \\
\hline Sippighat & 274.93 & 37.73 & 115.61 & 5.64 & 127.23 \\
\hline Badmasphar & 24.58 & 2.13 & 7.15 & 1.03 & 16.33 \\
\hline Mithagari & 23.83 & 6.61 & 9.53 & 0.48 & 8.17 \\
\hline Total & $\mathbf{3 8 8 . 8 1}$ & $\mathbf{5 7 . 6 7}$ & $\mathbf{1 7 6 . 9 2}$ & $\mathbf{9 . 1 8}$ & $\mathbf{1 6 3 . 4 0}$ \\
\hline
\end{tabular}

\section{Conclusion}

Spatial-temporal variation of South Andaman shoreline in response to mangrove forests was studied by using remote sensing and GIS methods. Tsunami inundation results in the sea level rise in the areas of Dolly Gunj, Garacharma, Sippighat, Badmasphar and Mithagari. Both the shoreline change map and mangrove distribution map was overlaid and then the mangrove dynamics and degradation for the tsunami impacts was observed and evaluated. It was estimated that 57.67 ha was submerged and 176.92 ha of mangroves was affected due to tsunami inundation and the persisting sea level rise, these environmental changes results in degradation of seaward mangrove and migration of mangrove to the landward side. Rejuvenation of mangrove occurs in the study area was 9.18 ha it express that mangrove have the tolerant and habitat alteration capacity for the environmental changes. The present status of the mangrove in flat bay coast was estimated 163.40 ha. Tsunami inundated areas in the land providing the suitable habitat for the mangrove juvenile growth. This study argues the need of monitoring the mangrove ecosystem by the geospatial technique to study the distribution and dynamic for the environmental stress. Hyper-spectral and Microwave Remote Sensing studies are the modern technologies which have wide significance on mapping and monitoring mangroves species level distribution. It is in need to identify suitable wetland for planting wide variety of mangrove species in for the sustainable growth of these threatened ecosystems. 


\section{Reference}

[1] Alongi DM. Present state and future of the world's mangrove forests. Environmental Conservation 29, $2002,331-349$.

[2] Benjamin W. Heumann, Satellite remote sensing of mangrove forests: Recent advances and future opportunities. 2011

[3] Chapman, V.J. Salt marshes and salt deserts of the World. Interscience Publishers, New York, NY, 1960.

[4] Barbier, E.B. Natural barriers to natural disasters: Replanting mangroves after tsunami. Front. Ecol. Environ. 2006,4 , 124-131. Progress in Physical Geography, 35(1) 87-108

[5] ISRO. Island Ecosystem for Andaman and Nicobar. Department of Ocean Development, Government of India, status report 2003.

[6] Chan, H.T.; Baba, S. Manual on Guidelines for Rehabilitation of Coastal Forests Damaged by Natural Hazards in the Asia-Pacific Region. International Society for Mangrove Ecosystems (ISME) and International Tropical Timber Organization (ITTO): Okinawa, Japan, 2009; p. 66.

[7] Gilman, E.; Ellison J.; Duke, N.C and Field, C. Threats to mangroves from climate change and adaptation options: a review. Aquatic Botany, 89(2), 2008, 237-250.

[8] Dharanirajan. K, Kasinathapandian. P, Gurugnanam. B, Narayanan. R.M, Ramachandran. S. An Integrated study for the Assessment of Tsunami impacts: A case study of South Andaman Island, India using Remote Sensing and GIS. Coastal Engineering Journal vol.49, 2006, $229-226$.

[9] Sudhir, K. Jain, Murty, C., Javed Malik, V. R., Rai, C., Alpa Sheth, Pratibha Gandhi, Arvind Jaiswal, Snigdha Sanyal, Sodhi \& Santhosh Kumar. Quick Report on the Study of the 2004 Sumatra Earthquake and Tsunami Effects, Department of Civil Engineering, Indian Institute of Technology Kanpur, http://www.nicee.org/EQ_Reports/Andaman /AndamanReport. pdf., 2005

[10] IPCC. Climate change 1995 - Impacts, adaptations and mitigation of climate change: scientific-technical analysis. Cambridge University Press, Cambridge, 1996

[11] Gilman, E. Assessing and managing shoreline response to projected relative sea-level rise and climate change. UNESCO World Heritage Central Pacific Project Planning Workshop, Kiritimati Island, Republic of Kiribati, 5-9 October 2004.

[12] Naidoo, G. Effects offlooding on leaf water potential and stomatal resistance in Bruguiera gymnorrhiza. New Phytol-ogist, 93, 1983, $369-373$

[13] Lewis, R.R. Ecological engineering for successfulmanagement and restoration of mangrove forests. Ecological Engineering, 24 (4 SI), 2005 403-418.

[14] Eric Gilman, Joanna Ellison, Richard Coleman (2007) Assessment of mangrove response to projected relative sea-level rise and recent historical reconstruction of shoreline position. Springer science, Environ Monit Assess, issue 124, 2007, 105-130

[15] Department of Ocean Development. Preliminary Assessment of Impact of Tsunami in Selected Coastal Areas of India. Report - 2005 of Integrated Coastal Marine Area Management Project Directorate, Chennai, India.

[16] Subramanian.B.R, Ramanamurthy.M.V, Sundaramoorthy.S, Pari.Y, Ranga Rao.V, Mishra.P, Bhat. M, Tune Usha, Venkatesan.R, , Inundation of sea water in Andaman and Nicobar Islands and parts of Tamil Nadu coast during 2004 Sumatra tsunami, Current Sciene, Vol. 88, No. 11, June 2005, 1736-1740.

[17] Dam Roy. S and Krishnan. P (2005) Mangrove stands of Andamans vis-à-vis tsunami. Current Science, Vol. 89, No. 11, 10 December 2005, 1080-1084

[18] Green, E.P.; Mumby, P.J.; Edwards, A.J.; Clark, C.D.; Ellis, A.C. The assessment of mangrove areas using high resolution multispectral airborne imagery. J. Coast. Res. 1998, 14, 433-443

[19] Giri, C.; Pengra, B.; Zhu, Z.; Singh, A.; Tieszen, L.L. Monitoring Mangrove forest dynamics of the Sundarbans in Bangladesh and India using multi-temporal satellite data from 1973 to 2000. Estuar. Coast. Shelf Sci. 2007, 73, 91-100.

[20] Ibrahim and Yuson. 1992 . Remote Sensing of Mangrove estimation in Andaman and Nicobar Islands.

[21] Kumudranjan Naskar, Manual of Indian Mangroves (Daya publishing house, 2004) 